\title{
Physical and Biochemical Properties of Apple Orchard Soils of Different Productivities
}

\author{
Takamitsu Kai, Masaki Mukai, Kiwako S. Araki, Dinesh Adhikari, Motoki Kubo* \\ Department of Biotechnology, Faculty of Life Sciences, Ritsumeikan University, Biwako-Kusatsu Campus, \\ Kusatsu, Shiga 525-8577, Japan \\ Email: ${ }^{*}$ kubo@sk.ritsumei.ac.jp
}

Received 16 May 2015; accepted 10 July 2015; published 13 July 2015

Copyright (C) 2015 by authors and Scientific Research Publishing Inc.

This work is licensed under the Creative Commons Attribution International License (CC BY). http://creativecommons.org/licenses/by/4.0/

c) (i) Open Access

\begin{abstract}
Physical and biochemical properties of apple orchard soils of different productivities (orchard A: $30 \mathrm{t}^{\cdot} \cdot \mathrm{ha}^{-1}$; orchard B: $20 \mathrm{t} \cdot \mathrm{ha}^{-1}$ ) were analyzed. Most of the physical properties were similar in both orchards. In orchard A, the horizontal saturated hydraulic conductivity at 10-cm depth was 16.42

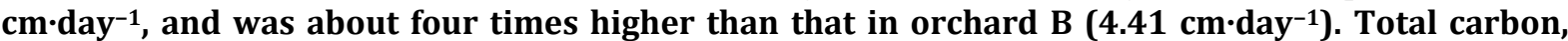
total nitrogen, and total phosphorus were about two times higher in orchard B soil, whereas total potassium, bacterial biomass, nitrification, and phosphorus mineralization activities were similar in both orchards. Excess nutrients accumulated on the top $15 \mathrm{~cm}$ layer of orchard B soil because the topographical and physical conditions were associated with reduced apple productivity. Appropriate management of fallen leaves and reduction of chemical fertilizer seem necessary for a high level of apple productivity.
\end{abstract}

\section{Keywords}

Apple Orchard Soil, Physical Properties, Biochemical Properties, Fruit Yield

\section{Introduction}

Apple (Malus domestica Borkh.) is cultivated in most of the world's temperate regions, including Japan, where it is one of the country's oldest crops [1] [2]. Apple cultivation became widespread following the importation of 75 cultivars from America in 1871 [3]. It is cultivated mainly in the northern part of Japan, viz. Aomori, Nagano, Iwate, Yamagata, Akita, and Fukushima prefectures. Aomori and Nagano prefectures are the two major apple-

*Corresponding author.

How to cite this paper: Kai, T., Mukai, M., Araki, K.S., Adhikari, D. and Kubo, M. (2015) Physical and Biochemical Properties of Apple Orchard Soils of Different Productivities. Open Journal of Soil Science, 5, 149-156.

http://dx.doi.org/10.4236/ojss.2015.57015 
producing areas, contributing about $77 \%$ of the national production [4]. Average productivity of apple in Japan during 2012 was $21.2 \mathrm{t} \cdot \mathrm{ha}^{-1}$, which was lower than that in other developed countries, such as $77.9 \mathrm{t} \cdot \mathrm{ha}^{-1}$ in Austria, $47.4 \mathrm{t} \cdot \mathrm{ha}^{-1}$ in New Zealand, and $31.9 \mathrm{t} \cdot \mathrm{ha}^{-1}$ in the USA [5].

Apple requires deep and well-drained soil with a pH of 5.5 to 6.5 [6]. Soils rich in organic matter and high in available nitrogen, phosphorus, and potassium are suitable for its cultivation. Apple is cultivated conventionally in Japan, relying on use of chemical fertilizers and pesticides [4]. Recommendations for chemical fertilizers are generally based on the soil nutrient status and rate of plant uptake [7]. Some fertilizer recommendations for apple are based on leaf nutrient analyses, because orchard soils receive additional nutrients from fallen leaves [8][10]. However, most producers in Japan apply fertilizers based on national recommendations as follows: $144 \mathrm{~kg}$ $\mathrm{N}, 72 \mathrm{~kg} \mathrm{P} \mathrm{O}_{5}, 48 \mathrm{~kg} \mathrm{~K}$ O, $4.8 \mathrm{~kg} \mathrm{MnO}$, and $2.4 \mathrm{~kg} \cdot \mathrm{B} \cdot \mathrm{ha}^{-1} \cdot \mathrm{year}^{-1}$ [4].

Low apple productivity has been reported from several orchards in Japan. Although poor soil fertility is one of the major problems causing lower apple production in several prefectures [11], there is limited information on the interrelationship between soil properties and apple productivity [12] [13]. Assessment of soil properties could help to improve soil management and enhance productivity on marginal sites.

In this study, physical and biochemical properties of soils from two orchards with different productivities were analyzed with the goal being to improve apple production on marginal sites. In addition, nutrient status of leaves and fruit was analyzed in relation to soil properties and orchard productivity.

\section{Materials and Methods}

\subsection{Study Area}

This study was conducted in two adjacent apple orchards located in Iizuna Town in Nagano Prefecture $\left(36^{\circ} 26^{\prime} 44.3^{\prime \prime} \mathrm{N}\right.$ and $\left.138^{\circ} 9^{\prime} 11.6^{\prime \prime} \mathrm{E}\right)$. The local climate is humid temperate, where July is the warmest month and January is the coolest month. The main orchard in the study site is distributed along a north-facing slope with 32-year-old Fuji/Marubakaido (Malus prunifolia Borkh. var. ringo Asami). The two orchard blocks (0.3 haeach) selected for this study are situated along a south-facing slope. Each orchard block consists of 15 trees (spacing: $16.6 \mathrm{~m} \times 12 \mathrm{~m}$ ). The orchard blocks on uphill (orchard A) and downhill (orchard B) positions are higher and lower in productivity, respectively (Figure 1). The slope between the orchards was $12.2 \%$ with horizontal and vertical distances of $90 \mathrm{~m}$ and $11 \mathrm{~m}$, respectively. Fertilizers were applied at the rate of $144 \mathrm{~kg} \mathrm{~N}, 72 \mathrm{~kg} \mathrm{P}_{2} \mathrm{O}_{5}, 48$ $\mathrm{kg} \mathrm{K}_{2} \mathrm{O}, 4.8 \mathrm{~kg} \mathrm{MnO}$, and $2.4 \mathrm{~kg} \mathrm{~B} \cdot \mathrm{ha}^{-1}$. Total fertilizer is split into two halves and applied in December (after harvesting) and in March (before flowering). Pesticides, irrigation, and cultural operations are applied as per the recommendations for Nagano Prefecture by the Japanese Government [14].

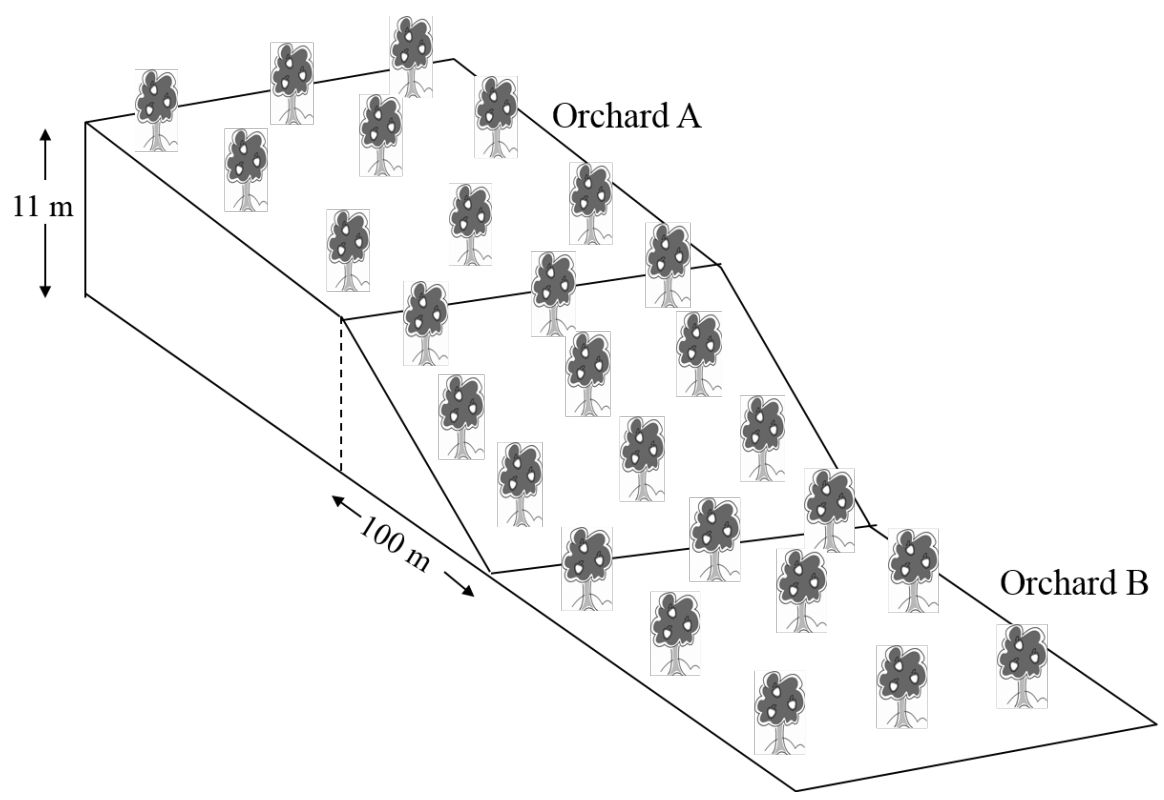

Figure 1. Schematic diagram of the two apple orchards used in this study. 


\subsection{Determination of Physical Properties}

The following physical properties of soils at $15 \mathrm{~cm}$ and $35 \mathrm{~cm}$ depths were analyzed: color, texture, bulk density, porosity, soil solid, soil air, soil water, and hydraulic conductivity. Soil color was determined using Munsell Soil Color Charts [15]. The three soil phases were measured by a soil three-phase meter (Daiki Rika Kogyo Co., Ltd., Saitama, Japan), which is a type of gas pycnometer. Gaseous phase, total porosity and water saturation percentage were then calculated. Wet and dry bulk densities were estimated from the oven-dried mass of the solid phase in core samples. Vertical and horizontal saturated hydraulic conductivity were analyzed by the falling head permeability test using a falling head permeameter (Model: DIK-4050; Daiki Rika Kogyo Co., Ltd., Saitama, Japan).

\subsection{Biochemical Properties of Soils}

Composite soils samples (top $15 \mathrm{~cm}$ layer excluding the $2-3 \mathrm{~cm}$ surface crust) were takennearthe bases of five randomly selected trees in April, July, and December. The following biochemical properties of the composite soil samples were analyzed: $\mathrm{pH}$, total carbon (TC), ammonium-nitrogen $\left(\mathrm{NH}_{4}^{+}-\mathrm{N}\right)$, nitrate-nitrogen $\left(\mathrm{NO}_{3}^{-}-\mathrm{N}\right)$, total nitrogen (TN), water soluble phosphorus (SP), total phosphorus (TP), water soluble potassium (SK), total potassium (TK), total bacterial biomass, nitrification activity, and phosphorus mineralization activity. TC was analyzed with a TOC analyzer (Model: SSM-5000A, Shimadzu, Kyoto, Japan). $\mathrm{NH}_{4}^{+}-\mathrm{N}$ was analyzed by extracting the soil sample with $1 \mathrm{~N} \mathrm{KCl}$. Soil-water suspension $(1: 20, \mathrm{w} / \mathrm{v})$ was shaken reciprocally at $100 \mathrm{rpm}$ for $1 \mathrm{~h}$ and the extracts were analyzed for $\mathrm{NO}_{3}^{-}-\mathrm{N}, \mathrm{SP}$, and $\mathrm{SK}$ by brucine, indophenol blue method and atomic absorption spectrophotometry, respectively. The same methods were used to detect TN, TP, and TK by digesting soils in a Kjeldahltherm (Gerhardt, Königswinter, Germany) with $\mathrm{H}_{2} \mathrm{SO}_{4}$ and $\mathrm{H}_{2} \mathrm{O}_{2}$. The $\mathrm{pH}$ of the soil-water suspension $(1: 2.5, \mathrm{w} / \mathrm{v})$ was analyzed.

Total bacterial biomass was estimated by quantification of environmental DNA (eDNA) using the slow-stirring method following the procedures of Aoshima et al. [16]. Nitrification activity was analyzed by pooling the values of ammonium oxidizing activity, nitrite oxidizing activity, and total bacterial number. Ammonium and nitrite oxidizing activities were estimated by analyzing the percent reduction in $\mathrm{N}$ during an incubation period of 3 days at $25^{\circ} \mathrm{C}$ in the soil samples with added ammonium sulfate and sodium nitrate, respectively. Similarly, phosphorus mineralization activity was estimated following the procedures of Horii et al. [17] by analyzing percent increment in SP from the substrate (phytic acid) under similar incubation conditions.

\subsection{Nutrient Contents in Leaves and Fruits, Soluble Sugar Content, and Yield}

Leaf and fruit samples were collected at different growth stages for chemical analysis. TN, TP, and TK in leaves and fruits were analyzed by digestion following the same procedures described above for soil samples. Soluble sugar content in the ripened fruit was analyzed with a palette digital refractometer (Model: DBX-55; ATAGO, Tokyo, Japan). Fruit were harvested during December, and yields were recorded separately for each orchard block.

\section{Results}

\subsection{Weather}

Weather data averaged over a 31-year period (1980 to 2010) shows that the site annually receives sunshine and precipitation of 1931 hours and $930 \mathrm{~mm}$, respectively (Figure 2). The sunshine duration, precipitation, and temperature around the site during the study period (2011) were similar to normal, except for higher than normal rainfall during May.

\subsection{Soil Physical Properties}

Physical properties of soils at different depths in two orchards were analyzed during April 2011. The colors of the surface $(0 \mathrm{~cm}$ to $15 \mathrm{~cm})$ and sub-surface $(15 \mathrm{~cm}$ to $40 \mathrm{~cm})$ in orchard A were dark brown $(7.5 \mathrm{YR} 4 / 4)$ and brown (7.5YR 3/3), respectively (Figure 3). Those of the surface and sub-surface in orchard B were dark brown (7.5YR 4/4). Likewise, textures of the surface and sub-surface soils in orchard A were clay loam and light clay, respectively, and those of the surface and sub-surface in orchard B were clay loam. 


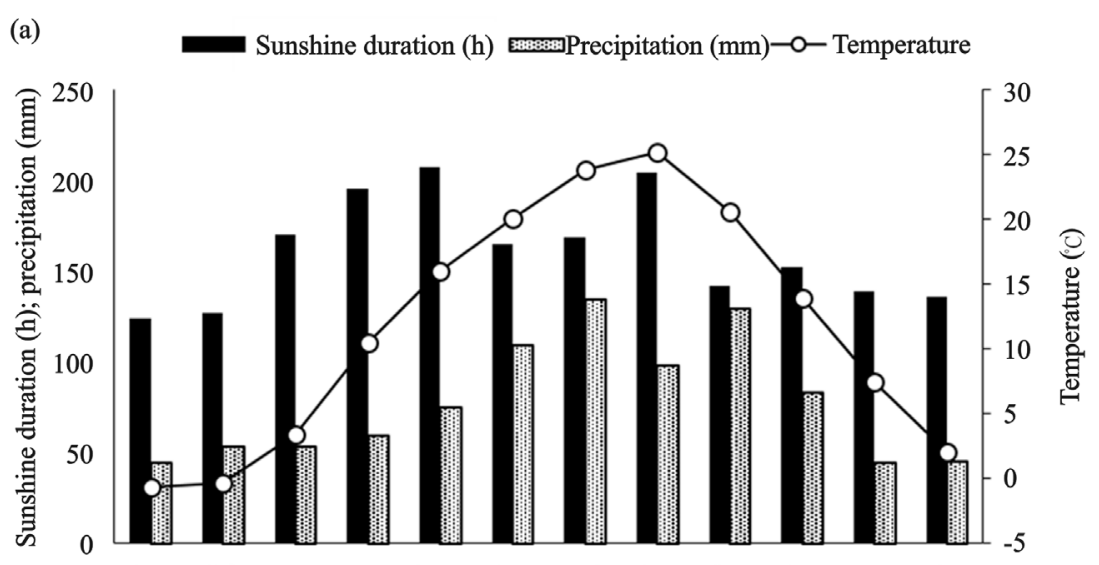

(b)

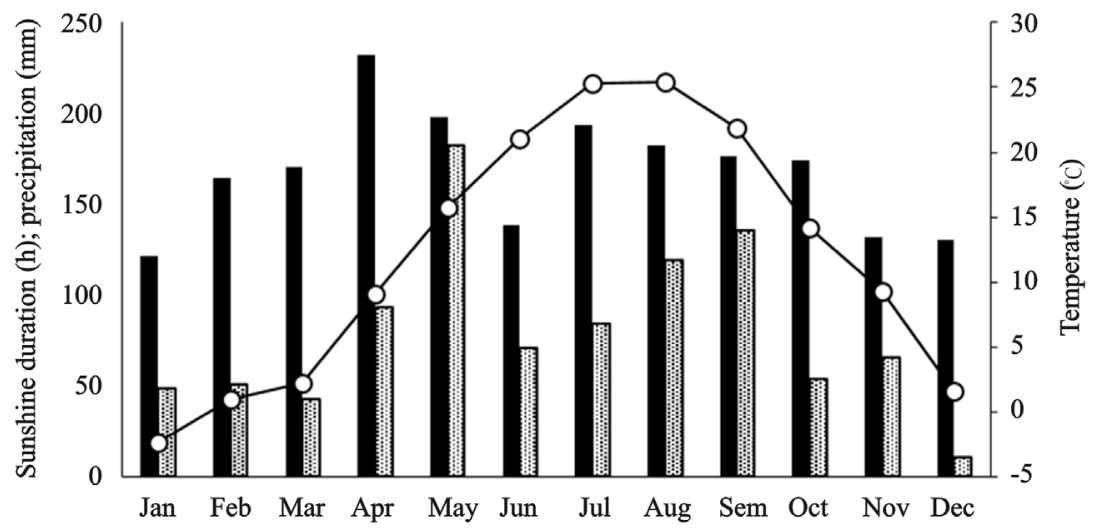

Figure 2. Monthly averages of sunshine duration, precipitation, and temperature around of the study site during 1980 and 2010 (a) and in 2011 (b).

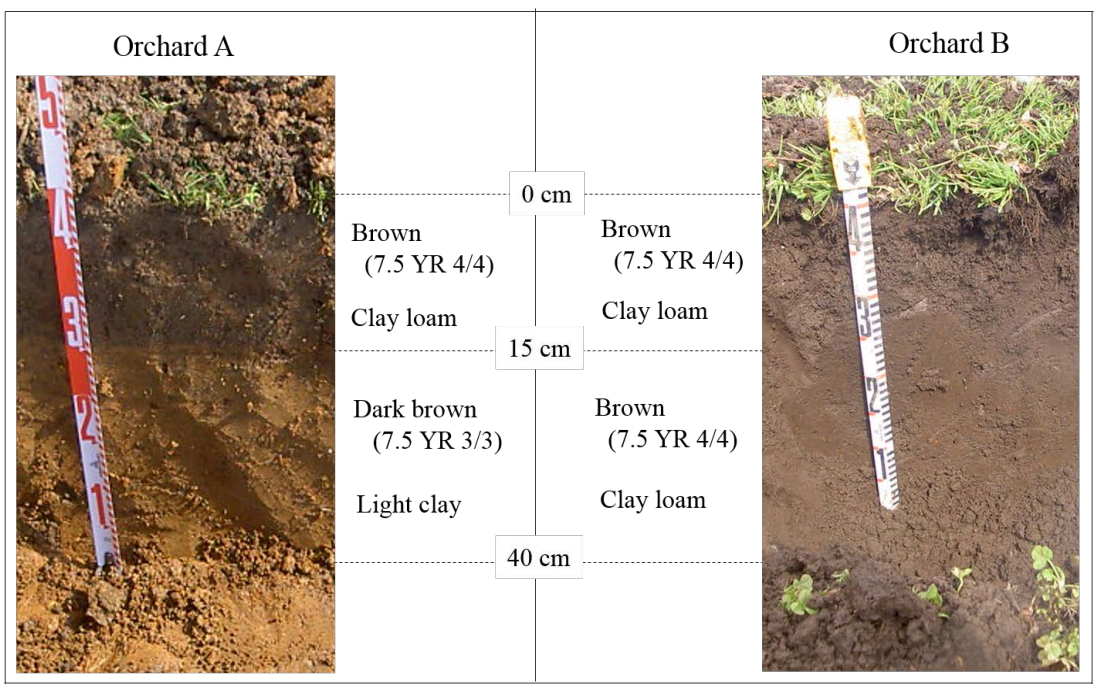

Figure 3. Soil profiles of orchard A and B showing color and texture at different depths. Photographs were taken on April, 2011.

Clear differences in dry and wet bulk densities of soils between the two orchards were not observed, except for dry bulk density at $10 \mathrm{~cm}\left(1.420 \mathrm{~g} \cdot \mathrm{cm}^{-3}\right.$ and $1.296 \mathrm{~g} \cdot \mathrm{cm}^{-3}$ in orchards A and B, respectively; Table 1). Relative proportions of soil solids, water, and air also did not differ between the two orchards, except for the porosity 
at $10 \mathrm{~cm}(46.70 \%$ in orchard A and $50.25 \%$ in orchard B). Similarly, no clear differences in vertical saturated hydraulic conductivity were observed between orchards A and B (Table 1). In contrast, the horizontal hydraulic conductivity at $10-\mathrm{cm}$ depth of orchard A soil was 3.7 times greater than that in orchard B $\left(16.42 \mathrm{~cm} \cdot \mathrm{day}^{-1}\right.$ in orchard A and $4.41 \mathrm{~cm} \cdot$ day $^{-1}$ in orchard B), while the horizontal hydraulic conductivity at $35-\mathrm{cm}$ depth in orchard A was 1.7 times higher than that in orchard B.

\subsection{Soil Biochemical Properties}

Bacterial biomass, nitrification activity, and phosphorus mineralization activity were almost equal between orchards A and B when examined in April, July, and December (Table 2). Bacterial biomass in soils of both orchards gradually increased from April to December. In contrast, nitrification activity gradually decreased during this period. Phosphorus mineralization activity was highest in July.

Concentrations of TC, TN, and TP were almost two times higher in orchard B than in orchard A (Table 2). Similarly, concentrations of $\mathrm{NO}_{3}^{-}-\mathrm{N}$, SP, and SK were also higher in orchard B. The large differences in nutrients show that organic materials and inorganic ions are accumulated in orchard $\mathrm{B}$.

Table 1. Physical properties of soils in two apple orchards.

\begin{tabular}{|c|c|c|c|c|}
\hline \multirow{2}{*}{ Property } & \multicolumn{2}{|c|}{ Orchard A } & \multicolumn{2}{|c|}{ Orchard B } \\
\hline & $10 \mathrm{~cm}$ & $35 \mathrm{~cm}$ & $10 \mathrm{~cm}$ & $35 \mathrm{~cm}$ \\
\hline Gravimetric water $(\mathrm{w} / \mathrm{w})(\%)$ & 24.40 & 35.10 & 27.70 & 25.60 \\
\hline Specific gravity & 2.66 & 2.73 & 2.61 & 2.66 \\
\hline Wet bulk density $\left(\mathrm{g} / \mathrm{cm}^{3}\right)$ & 1.78 & 1.64 & 1.67 & 1.60 \\
\hline Dry bulk density $\left(\mathrm{g} / \mathrm{cm}^{3}\right)$ & 1.42 & 1.21 & 1.30 & 1.28 \\
\hline Void ratio & 0.88 & 1.25 & 1.01 & 1.08 \\
\hline Porosity (\%) & 46.70 & 55.53 & 50.25 & 52.03 \\
\hline Degree of saturation (\%) & 74.05 & 76.77 & 71.44 & 62.65 \\
\hline Soil solid (v/v) (\%) & 53.30 & 44.47 & 49.75 & 47.97 \\
\hline Soil water (v/v) (\%) & 34.58 & 42.63 & 35.90 & 32.60 \\
\hline Soil air (v/v) $(\%)$ & 12.12 & 12.90 & 14.35 & 19.43 \\
\hline Vertical saturated hydraulic conductivity (cm/day) & 40.61 & 1.03 & 57.89 & 1.04 \\
\hline Horizontal saturated hydraulic conductivity ( $\mathrm{cm} /$ day) & 16.42 & 3.54 & 4.41 & 6.05 \\
\hline
\end{tabular}

Table 2. Biochemical properties of soils in two apple orchards.

\begin{tabular}{|c|c|c|c|c|c|c|}
\hline \multirow{2}{*}{ Property } & \multicolumn{3}{|c|}{ Orchard A } & \multicolumn{3}{|c|}{ Orchard B } \\
\hline & Apr & Jul & Dec & Apr & Jul & Dec \\
\hline Nitrification activity $(\%)$ & 96 & 59 & 33 & 92 & 77 & 33 \\
\hline Bacterial biomass $\left(\times 10^{9}\right.$ cells $\cdot \mathrm{g}^{-1}$ soil $)$ & 1.4 & 1.7 & 1.8 & 1.3 & 1.6 & 1.7 \\
\hline $\mathrm{NH}_{4}^{+} \quad$ oxidation activity $(\%)$ & 93 & 38 & 0 & 96 & 66 & 0 \\
\hline $\mathrm{NO}_{2}^{-}$oxidation activity (\%) & 100 & 100 & 100 & 91 & 100 & 100 \\
\hline $\mathrm{P}$ mineralization activity $(\%)$ & 23 & 96 & 47 & 39 & 100 & 53 \\
\hline $\mathrm{pH}$ & 7.0 & 7.4 & 7.5 & 7.2 & 7.6 & 6.8 \\
\hline Total carbon (TC) (mg/kg) & 35,700 & 45,900 & 46,900 & 59,800 & 85,600 & 67,400 \\
\hline Total nitrogen $(\mathrm{TN})(\mathrm{mg} / \mathrm{kg})$ & 4100 & 4500 & 5100 & 10,500 & 8500 & 7500 \\
\hline $\mathrm{NH}_{4}^{+}-\mathrm{N} \quad(\mathrm{mg} / \mathrm{kg})$ & 2 & 3 & 8 & 3 & 3 & 2 \\
\hline $\mathrm{NO}_{3}^{-}-\mathrm{N} \quad(\mathrm{mg} / \mathrm{kg})$ & 0 & 4 & 0 & 8 & 20 & 2 \\
\hline $\mathrm{C} / \mathrm{N}$ ratio & 9 & 10 & 9 & 6 & 10 & 9 \\
\hline Total phosphorus (TP) (mg/kg) & 1280 & 1140 & 900 & 2720 & 2900 & 2720 \\
\hline Soluble phosphorus (SP) (mg/kg) & 20 & 10 & 30 & 200 & 190 & 55 \\
\hline Total potassium (TK) (mg/kg) & 5300 & 4700 & 4300 & 5300 & 4700 & 5000 \\
\hline Soluble potassium $(\mathrm{SK})(\mathrm{mg} / \mathrm{kg})$ & 151 & 140 & 350 & 840 & 420 & 340 \\
\hline
\end{tabular}




\subsection{Nutrient Concentrations in Plant Tissues, Fruit Soluble Sugar, and Yield}

Concentrations of TN, TP, and TK in the leaves were determined (Table 3). TP and TK were higher in orchard A in July and December. Leaf TN in orchard A was higher than in orchard B in July, but not in December. Nutrient concentrations in fruit also differed between orchards A and B (Table 4). Concentrations of TN, TP, and TK in fruit were higher in orchard A at both stages compared with those in orchard B. Soluble solids were also higher in orchard A. The results indicate that soil properties can affect the levels of nutrients in apple leaves and fruit.

\section{Discussion}

To improve the productivity of apple, physical and biochemical properties of soils and nutrient concentrations in leaves and fruit were investigated in two apple orchards with different productivities. Several characteristic differences between the two orchards indicate that apple productivity can be improved with greater attention to soil properties.

Apple productivity and soil nutrient status in two orchards were oppositely related in this study. Lower apple productivity in orchard B may be due to the toxicity of TN and TP. The slope of the land from orchard A to orchard B may have favored leaching of nutrients towards orchard B. Apple trees can grow vigorously and produce good yield with optimum supply of nitrogen and phosphorus. Excessive nitrogen application increases tree growth and leaf nitrogen content, but negatively affects fruit yield and quality [18]. In a similar study, a very high nitrogen application caused for the reduction in trunk size, tree height, and floral buds [19].

Leaf litter contributes significant amounts of biomass and nutrients to orchard soil [10] [20]. It is reported that approximately $30 \mathrm{~kg} \cdot \mathrm{N} \cdot \mathrm{ha}^{-1}$ is contained in leaves that fall each year [21]. In this study, nutrients and biomass from the fallen leaves may contribute to the higher accumulation of TC, TN, and TP in orchard B soil.

Hydraulic conductivity is an important factor for productivity of orchards. In this study, lower apple productivity in orchard B was associated with the lower hydraulic conductivity. Previous studies have shown reduction

Table 3. Nutrient concentrations in leaves of apple grown in two orchards.

\begin{tabular}{ccccc}
\hline \multirow{2}{*}{ Property } & \multicolumn{2}{c}{ Orchard A } & \multicolumn{2}{c}{ Orchard B } \\
\cline { 2 - 5 } $\mathrm{TC}\left(\mathrm{mg} \cdot \mathrm{kg}^{-1}\right)$ & Jul & Dec & Jul & Dec \\
$\mathrm{TN}\left(\mathrm{mg} \cdot \mathrm{kg}^{-1}\right)$ & 422,500 & 491,500 & 433,800 & 485,300 \\
$\mathrm{NO}_{3}^{-}-\mathrm{N}\left(\mathrm{mg} \cdot \mathrm{kg}^{-1}\right)$ & 18,900 & 22,000 & 25,200 & 21,200 \\
$\mathrm{TP}\left(\mathrm{mg}^{-1} \mathrm{~kg}^{-1}\right)$ & 80 & 700 & 60 & 690 \\
$\mathrm{SP}\left(\mathrm{mg} \cdot \mathrm{kg}^{-1}\right)$ & 1800 & 2410 & 1520 & 2030 \\
$\mathrm{TK}\left(\mathrm{mg} \cdot \mathrm{kg}^{-1}\right)$ & 870 & 260 & 620 & 190 \\
$\mathrm{SK}\left(\mathrm{mg} \cdot \mathrm{kg}^{-1}\right)$ & 14,900 & 20,100 & 12,700 & 16,600 \\
& 8650 & 20,550 & 6910 & 16,400 \\
\hline
\end{tabular}

Table 4. Nutrient concentrations in fruit and yield of apple grown in two orchards.

\begin{tabular}{|c|c|c|c|c|}
\hline \multirow{2}{*}{ Property } & \multicolumn{2}{|c|}{ Orchard A } & \multicolumn{2}{|c|}{ Orchard B } \\
\hline & Jul & Dec & Jul & Dec \\
\hline $\mathrm{TC}\left(\mathrm{mg} \cdot \mathrm{kg}^{-1}\right)$ & 390,400 & 415,000 & 380,700 & 413,000 \\
\hline $\mathrm{TN}\left(\mathrm{mg} \cdot \mathrm{kg}^{-1}\right)$ & 10,100 & 2400 & 9200 & 2600 \\
\hline $\mathrm{NO}_{3}^{-}-\mathrm{N} \quad\left(\mathrm{mg} \cdot \mathrm{kg}^{-1}\right)$ & 50 & 600 & 80 & 880 \\
\hline $\mathrm{TP}\left(\mathrm{mg} \cdot \mathrm{kg}^{-1}\right)$ & 1410 & 850 & 1100 & 830 \\
\hline $\mathrm{SP}\left(\mathrm{mg} \cdot \mathrm{kg}^{-1}\right)$ & 840 & 680 & 500 & 500 \\
\hline $\mathrm{TK}\left(\mathrm{mg} \cdot \mathrm{kg}^{-1}\right)$ & 10,900 & 11,900 & 8700 & 10,100 \\
\hline $\mathrm{SK}\left(\mathrm{mg} \cdot \mathrm{kg}^{-1}\right)$ & 7540 & 11,500 & 5750 & 9380 \\
\hline Soluble sugar (\%) & - & 16.6 & - & 15.4 \\
\hline Yield $\left(\mathrm{t} \cdot \mathrm{ha}^{-1}\right)$ & - & 30.0 & - & 20.0 \\
\hline
\end{tabular}


in hydraulic conductivity in the soils rich in organic matter [22]-[24]. Accumulation of organic matter in orchard B may have reduced the hydraulic conductivity in this study. Soils with a high amount of litters, pore spaces are partially clogged by degraded organic materials [25].

Large amounts of nutrients in soils often result in over-uptake and imbalanced uptake of nutrients, and quality and quantity of apple can be adversely affected [26]-[28]. A negative relationship between soil nutrient content and fruit yield in this study indicates that chemical fertilizers should be carefully applied. Moreover, judging from the accumulation of nutrients, appropriate management of fallen leaves from the orchard is also an important factor for continuing a high level of apple productivity. Better management of biological and chemical properties of orchard soils is necessary for improving apple productivity.

\section{References}

[1] Forsline, P.L., Aldwinckle, H.S., Dickson, E.E., Luby, J.J. and Hokanson, S.C. (2003) Collection, Maintenance, Characterization, and Utilization of Wild Apples of Central Asia. Horticultural Reviews: Wild Apple and Fruit Trees of Central Asia, 29, 1-62.

[2] Cornille, A., Gladieux, P., Smulders, M.J., Roldán-Ruiz, I., Laurens, F., Le Cam, B., Nersesyan, A., Clavel, J., Olonova, M., Feugey, L., Gabrielyan, I., Zhang, X.G. and Giraud, T. (2012) New Insight into the History of Domesticated Apple: Secondary Contribution of the European Wild Apple to the Genome of Cultivated Varieties. PLoS Genetics, 8 , e1002703. http://dx.doi.org/10.1371/journal.pgen.1002703

[3] Soejima, J., Bessho, H., Tsuchiya, S., Komori, S., Abe, K. and Kotoda, N. (1998) Breeding of Fuji Apples and Performance on JM Root Stocks. Compact Fruit Tree, 31, 22-24.

[4] MAFF (2014) Monthly Statistics of Agriculture, Forestry and Fisheries. Ministry of Agriculture, Forestry and Fisheries, Japan.

[5] FAO (2014) FAOSTAT. faostat3.fao.org/home/E

[6] Krishna, K.R. (2014) Agroecosystems: Soils, Climate, Crops, Nutrient Dynamics and Productivity. Apple Academic Press, Inc., Oakville. http://dx.doi.org/10.1201/b16300

[7] Neilsen, D. and Neilsen, G.H. (2002) Efficient Use of Nitrogen and Water in High-Density Apple Orchards. HorTechnology, 12, 19-25.

[8] Han, M.Y., Zhang, L.X., Fan, C.H., Liu, L.H., Zhang, L.S., Li, B.Z. and Alva, A.K. (2011) Release of Nitrogen, Phosphorus, and Potassium during the Decomposition of Apple (Malus domestica) Leaf Litter under Different Fertilization Regimes in Loess Plateau, China. Soil Science and Plant Nutrition, 57, 549-557. http://dx.doi.org/10.1080/00380768.2011.593481

[9] Tagliavini, M., Tonon, G., Scandellari, F., Quinones, A., Palmieri, S., Menarbin, G., Gioacchini, P. and Masia, A. (2007) Nutrient Recycling during the Decomposition of Apple Leaves (Malus domestica) and Mowed Grasses in an Orchard. Agriculture, Ecosystems and Environment, 118, 191-200. http://dx.doi.org/10.1016/j.agee.2006.05.018

[10] Tonon, G., Ciavatta, C., Solimando, D., Gioacchini, P. and Tagliavini, M. (2007) Fate of ${ }^{15}$ N Derived from Soil Decomposition of Abscised Leaves and Pruning Wood from Apple (Malus domestica) Trees. Soil Science and Plant Nutrition, 53, 78-85. http://dx.doi.org/10.1111/j.1747-0765.2007.00112.x

[11] Fujisawa, M. and Kobayashi, K. (2013) Shifting from Apple to Peach Farming in Kazuno, Northern Japan: Perceptions of and Responses to Climatic and Non-Climatic Impacts. Regional Environmental Change, 13, 1211-1222. http://dx.doi.org/10.1007/s10113-013-0434-6

[12] Dris, R. (2002) Influence of Orchard Management on Growth and Production of Fruits. In: Dris, T., Jain S.M. and Khan I.A., Eds., Environment and Crop Production, Science Publishers Inc., Enfield, NH, 1-3.

[13] Aggelopoulou, K.D., Wulfsohn, D., Fountas, S., Gemtos, T.A., Nanos, G.D. and Blackmore, S. (2010) Spatial Variation in Yield and Quality in a Small Apple Orchard. Precision Agriculture, 11, 538-556. http://dx.doi.org/10.1007/s11119-009-9146-9

[14] Nagano Agricultural Administration Department (2000) The Guide of Environment-Friendly Agricultural Technology.

[15] Munsell Color Company (1975) Munsell Soil Color Charts. Munsell Color Company, Baltimore.

[16] Aoshima, H., Kimura, A., Shibutani, A., Okada, C., Matsumiya, Y. and Kubo, M. (2006) Evaluation of Soil Bacterial Biomass Using Environmental DNA Extracted by Slow-Stirring Method. Applied Microbiology and Biotechnology, 71, 875-880. http://dx.doi.org/10.1007/s00253-005-0245-x

[17] Horii, S., Matsuno, T., Tagomori, J., Mukai, M., Adhikari, D. and Kubo, M. (2013) Isolation and Identification of Phytate-Degrading Bacteria and Their Contribution to Phytate Mineralization in Soil. The Journal of General and Applied Microbiology, 59, 353-360. http://dx.doi.org/10.2323/jgam.59.353 
[18] Komamura, K., Suzuki, A., Fukumoto, M., Kato, K. and Sato, Y. (2000) Effects of Long-Term Nitrogen Application on Tree Growth, Yield, and Fruit Qualities in a "Jonathan" Apple Orchard. Journal of the Japanese Society for Horticultural Science, 69, 617-623. http://dx.doi.org/10.2503/jjshs.69.617

[19] Ro, H.M. and Park, J.M. (2000) Nitrogen Requirements and Vegetative Growth of Pot-Lysimeter-Grown "Fuji" Apple Trees Fertilized by Drip Irrigation with Three Nitrogen Rates. Journal of Horticultural Science and Biotechnology, 75, 237-242.

[20] Kumar, K. and Goh, K.M. (1999) Crop Residues and Management Practices: Effects on Soil Quality, Soil Nitrogen Dynamics, Crop Yield, and Nitrogen Recovery. Advances in Agronomy, 68, 197-319. http://dx.doi.org/10.1016/S0065-2113(08)60846-9

[21] Haynes, R.J. and Goh, K.M. (1980) Some Effects of Orchard Soil Management on Sward Composition, Levels of Available Nutrients in the Soil, and Leaf Nutrient Content of Mature "Golden Delicious" Apple Trees. Scientia Horticulturae, 13, 15-25. http://dx.doi.org/10.1016/0304-4238(80)90017-5

[22] Marshall, M.R., Francis, O.J., Frogbrook, Z.L., Jackson, B.M., McIntyre, N., Reynolds, B., Solloway, I., Wheater, H.S. and Chell, J. (2009) The Impact of Upland Land Management on Flooding: Results from an Improved Pasture Hillslope. Hydrological Processes, 23, 464-475. http://dx.doi.org/10.1002/hyp.7157

[23] Gonzalez-Sosa, E., Braud, I., Dehotin, J., Lassabatère, L., Angulo-Jaramillo, R., Lagouy, M., Branger, M., Jacqueminet, C., Kermadi, S. and Michel, K. (2010) Impact of Land Use on the Hydraulic Properties of the Topsoil in a Small French Catchment. Hydrological Processes, 24, 2382-2399. http://dx.doi.org/10.1002/hyp.7640

[24] Archer, N.A.L., Bonell, M., Coles, N., MacDonald, A.M., Auton, C.A. and Stevenson, R. (2013) Soil Characteristics and Landcover Relationships on Soil Hydraulic Conductivity at a Hillslope Scale: A View towards Local Flood Management. Journal of Hydrology, 497, 208-222. http://dx.doi.org/10.1016/j.jhydrol.2013.05.043

[25] Oliveira, M.T. and Merwin, I.A. (2001) Soil Physical Conditions in a New York Orchard after Eight Years under Different Groundcover Management Systems. Plant and Soil, 234, 233-237. http://dx.doi.org/10.1023/A:1017992810626

[26] Drake S.R., Raese, J.T. and Smith, T.J. (2002) Time of Nitrogen Application and Its Influence on "Golden Delicious" Apple Yield and Fruit Quality. Journal of Plant Nutrition, 25, 143-157. http://dx.doi.org/10.1081/PLN-100108786

[27] Nava, G. and Dechen, A.R. (2009) Long-Term Annual Fertilization with Nitrogen and Potassium Affect Yield and Mineral Composition of "Fuji" Apple. Scientia Agricola, 66, 377-385. http://dx.doi.org/10.1590/S0103-90162009000300013

[28] Teravest, D., Smith, J.L., Carpenter-Boggs, L., Hoagland, L., Granatstein, D. and Reganold, J.P. (2010) Influence of Orchard Floor Management and Compost Application Timing on Nitrogen Partitioning in Apple Trees. HortScience, 45, 637-642. 